\title{
"HISTÓRIA, EDUCAÇÃO E PATRIMÔNIO": A IMPORTÂNCIA DA EDUCAÇÃO PATRIMONIAL
}

\author{
Marco Antonio Alves de Oliveira ${ }^{1}$ \\ Ana Enedi Prince ${ }^{2}$
}

Resumo: O objetivo desse artigo é discutir a importância que a Educação Patrimonial tem em relação à preservação do patrimônio histórico e cultural de uma sociedade. A conscientização proporcionada pela Educação Patrimonial, está relacionada a formação de cidadãos conscientes e com conhecimentos acerca da origem e desenvolvimento da região em que vivem, buscando a preservação da memória que remetem à esta história. Para o desenvolvimento dessa pesquisa, foram utilizados referenciais bibliográficos, depoimentos e observações, a partir de atividades desenvolvidas durante minha participação enquanto Bolsista do Programa Institucional de Bolsa de Iniciação à Docência, em um projeto denominado "Educação Patrimonial".

Palavras-chave: Patrimônio; Memória; Preservação; História; Educação Patrimonial.

\footnotetext{
${ }^{1}$ História/Universidade do Vale do Paraíba, Brasil. E-mail: marcoantonio_ao@hotmail.com.

2 História/Universidade do Vale do Paraíba, Brasil. E-mail: prince@univap.br.
} 